International Journal of Language Education

Volume 5, Number 4, 2021, pp. 285-295

ISSN: $2548-8457$ (Print) 2548-8465 (Online)

Doi: https://doi.org/10.26858/ijole.v5i4.19468

\title{
The Variability in Phonology of Indonesian Learner's Interlanguage: A case study on English marked-fricatives
}

\author{
Iwan Fauzi \\ Universitas Palangka Raya, Indonesia \\ Email:i_fauzi@edu.upr.ac.id
}

Received: 2 February 2021

Reviewed: 1 August 2021-29 October 2021

Accepted: 5 December 2021

\begin{abstract}
Interlanguage is the most fruitful issue in the field of second language acquisition. In the interlanguage phase, Indonesian learners of English tend to alternate between two forms of language features to express the same language function where a variation of language forms will be exhibited to mark the variable of linguistic function. Variability in phonology of interlanguage is the most interesting subject to investigate based on markedness differential hypothesis theory. This study is aimed at finding out (1) marked sounds of English fricatives: [ $\theta],[ð],\left[\int\right]$, and [3] which are indicated as interlanguage variants; and (2) how interlanguage sound variants emerge based on surround the varying element. There were 30 college students of English study purposively selected to become respondents in this research representing advance and intermediate proficiency of English speaking. The data were taken from two types of task namely word list reading and sentence reading. There were 600 -word tokens containing target marked sounds of fricative $[\theta],[\gamma],\left[\int\right]$, and [3] obtained from the data collection. The analysis was done quantitatively to find the percentages of non-interlanguge sounds and interlanguge ones produced by respondents. The result showed that fricatives such as $[\theta]$, [J], and [3] have phonological variations in interlanguage with certain positions of word being pronounced. These phonological variations emerge due to the generalization of pronunciation by similar-ending sounds, the certain vowel sound preceding marked sounds, and the absence of consonant clusters in learners' native language which bears the variation of certain marked fricatives of English.
\end{abstract}

Keywords: interlanguage; variability; markedness; English fricatives; phonology

\section{Introduction}

The concept of interlanguage was firstly proposed by Selinker (1972) in his seminal research paper Interlanguage. Since then interlanguage has been highly influential in the study of second language acquisition. Second language acquisition researchers of English learners note that interlanguage has certain features and characteristics which distinguish it from English spoken by its native speakers. Many studies provide evidence that the speech or writing of English learners in the phase of interlanguage is deviant with respect to native-speaker models. A huge sum of data reveals that the deviant English production yields the variability of linguistic features in terms of morphological, phonological, and syntactic units of the language. Interlanguage variability in phonology is one of interesting phenomena in second language acquisition where a second language learner uses two or more sound variants in expressing a language, which has only one 
realization in the target language. This research article aims to depict the interlanguage variability in phonology of Indonesian learners of English in pronouncing English marked-fricatives.

\section{Literature review}

\section{Definition of interlanguage}

Interlanguage has certain features and characteristics which distinguish it from the language spoken by native speakers of a language. According to Bialystok and Sharwood (1985) interlanguage implies that the speech of second language (L2) learners is deviant with respect to native-speaker models. They argue that interlanguage is systematic language performance of L2 speakers who have not achieved sufficient levels of analysis of linguistic knowledge or sufficient control of processing to be identified completely with native speakers.

The concept of interlanguage views learners as constructing their own grammatical systems. Nozadze (2012, p. 42) defines the grammatical systems of L2 learners in interlanguage are learner-driven rather than teacher-driven. She implies that the learner progresses through employing a number of different strategies, some of which are based upon the learner native language (L1) and some of which are based upon the learner's desire to communicate.

Many researchers give different definitions and descriptions of interlanguage. Three scholars of applied linguistics; Selinker (1972), Nemser (1971), and Corder (1971) have different terms used to refer to interlanguage. Selinker (1972), for instance, refers to it as the learner's intermediate language system while Nemser (1971) defines it as an "approximate" system. Then, Corder (1971) refers to what he calls an 'idiosyncratic' dialect or the learner's 'transitional competence'. According to Selinker (1972), the set of utterances for most learners of a second language is not identical to the hypothesized corresponding set of utterances which would have been produced by a native speaker of a target language had he attempted to express the same meaning as the learner. What Selinker defined here implies that there are two sets of utterances proving the existence of a separated linguistic system based on the utterance of the learner which is so-called interlanguage. Meanwhile, Nemser (1971) refers to the interlanguage system as an 'approximate system', where it is 'the deviant linguistic system actually employed by the learner attempting to utilize the target language" (p. 116). During the learning progress, Nemser (1971) added, the approximate system develops gradually from the first attempt to use the target language to the most advanced.

However, Corder (1971, p. 116) refers to the interlanguage system as an idiosyncratic dialect of the target language. The concept of idiosyncratic dialect is a development of Corder's earlier concept of 'transitional competence'. Corder argues that the interlanguage of L2 learners is a special sort of dialect that he describes as "the spontaneous speech of the second language learner which is a language and has a grammar. Therefore, the learner's language is a dialect in the linguistic sense; two languages which share some rules of grammar are dialects" (1981, p. 14). Then, Richard (1974, p. 161) interprets Corder's view above that the speech of learners of a second language is regular, systematic, and meaningful. The alternative name for idiosyncratic dialect is transitional dialect, a name emphasizing its unstable nature. Of all these, interlanguage is a language system that is neither the L1 nor the L2. Since interlanguage is considered as a separate linguistic system which is distinct from native language system and target language one, it is undeniable that interlanguage is, of course, characterized by the deviant linguistic features. 
Variability of phonology in interlanguage

Variability refers to cases where a second language learner uses two or more linguistic variants to express a phenomenon, which has only one realization in the target language (Song, 2012; 779). Interlanguage learners tend to alternate between two forms of language features to express the same language function where a variation of language forms will be exhibited to mark the variable of linguistic function. Ellis (1985a); and Gass and Selinker (2008, p. 259), for instance, describe the variable use of the two forms of negation no and not, such as in these sentences: (1) No look my card; and (2) My husband not here. Both bold words on these sentences are the variation of negation forms uttered by non-native speaker of English. This is the example of forms used by the learners of English in expressing the form of negation. Those typical sentences mostly occur in the interlanguage phase where to most applied linguists mean as the variation of learner's language.

The other data revealing the variability of interlanguage is that a cross-sectional study conducted by Gatbonton (1978) as cited in Gass and Selinker (2008, p. 260). He investigated the variability of interlanguage in the domain of phonology involving three sounds- $[\theta]$, as in thing; $[ð]$, as in soothe or the; and [h], as in behind. The findings show that learners begin with a single sound that is used in all linguistic environments. At a later point in time, a second sound enters the system. The second sound is then in free variation with the first. Later stages involve sorting the forms out into their appropriate environments. The study implies that there is a transition period which bears any variation of sounds to achieve the target-like forms.

In addition, Dickerson (1975) is one of the earliest studies to investigate the effects of phonological environment on the interlanguage system. She investigates the acquisition of sound $[\mathrm{r}]$ by ten Japanese learners of English over a nine-month period. She uses three different tasks, a word list, reading a dialogue and spontaneous free speech. The tasks are aimed at eliciting the most formal style during the reading of isolated words and the most informal speech in spontaneous conversation. She found that the target sound $[\mathrm{r}]$ was more frequently used before a low vowel

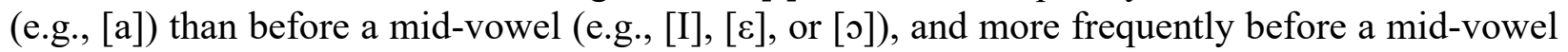
than before a high vowel ([i] or $[\mathrm{u}])$. From her research findings five pronunciation variants for English [r] are exemplified as a function of the phonetic environment in which the patternings differ depending on the following vowel. In relation to the phonetic environment, Ellis (1988) labels a term "surround" which is understood to mean features or sounds either coming before or after the varying element or both.

Meanwhile, Young (1991) investigated the use of plural markings by second language learners of Chinese native speakers in learning English. Young collected interview data from L2 subjects divided into two proficiency levels (High and Low) on the basis of their results on standardized test scores. Young, as cited in Gass and Selinker (2008, pp. 264-5) provided evidence for variation in the use and nonuse of the plural [s] even on the same lexical item. He found that there was variation conditioned by the phonological environment for low proficiency learners. For higher proficiency learners, the most important factor in determining whether or not plural nouns are marked with [s] is the presence or absence of plural markings elsewhere in the noun phrase. From this finding - in relation to the phonological environment, there are other factors that relate to plural marking. For example, Young found syntactic determinants as well as determinants based on the position of the noun within the NP. In fact, the greatest influence was the position of the noun within the NP (whether a pronominal modifier or head). 
Fricative marked-sounds acquired by English learners

Markedness theory has contributed to the field of second language acquisition. According to this approach, unmarked linguistic features are more neutral, universal and frequent whereas marked linguistic features are more specific and less frequent. Unmarked features are acquired earlier than marked features (Celce-Murcia et al., 1996). Eckman (1977), as cited in Osborne (2008, p. 113), proposed the Markedness Differential Hypothesis (MDH), in which markedness theory is applied to second language phonology acquisition. It claims that L2 learners will acquire unmarked structures faster than marked ones. In relation to this research, the unmarked linguistic features are English sounds which are familiar to English learners and categorized not to be difficult to pronounce. In contrast, the marked linguistic features are English sounds which belong to be complicated to be pronounced by the learners.

In relation to interlanguage phonology where English is regarded as the second or foreign language, several studies investigated English fricatives which belong to be difficult to be pronounced by L2 learners. Utumber, et.al., (2014) study the variants of phonology sounds [ $\theta$ ], $[ð],\left[\int\right]$ and [t $\left.\int\right]$ among TESL students in different races which are Malays, Chinese, Indians and other races in Malaysia. They adopt Labov's model to analyze some sounds by using four parts of his model which are careful style, word list style, minimal pair style and reading style. The findings indicate that the majority of Indians managed to pronounce the [ $\theta]$ and [ð] sound correctly. Other races like Malay, Chinese and other ethnics were unable to pronounce the $[\theta]$ and [ð] sound correctly. This is because they do not have this sound in their native sound system. Only a small

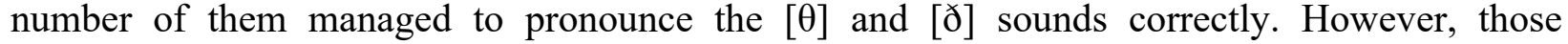
respondents who were able to pronounce the $[\theta]$ and $[ð]$ sounds correctly were inclined to English language.

The error of interlanguage in fricative sounds has also been investigated by Djajadiningrat's (2011) where the participants with the L1 of Indonesian erroneously pronounced the [ð] sound in the medial position with the highest frequency reaching $80 \%$, compared to the other initial and final positions. They also substituted the $[\mathrm{t}]$ or $[\mathrm{d}]$ sounds for the target sound in the initial and medial positions. This is in line with Jehma and Phoocharoensil (2014) investigating the acquisition of English fricatives among Thai Pattani-Malay learners. The findings show L1 Pattani-Malay had difficulty in pronouncing the voiced interdental fricative [ð] where all the participants wrongly pronounced the target sound [ð] in the medial position. They substituted the sounds which exist in their L1, namely [d], [t] and [J] for the target sound [ð] due to the L1 transfer. This is also similar to Fauzi (2018) in his study on English pronunciation where some English consonant sounds are difficult to be pronounced by certain ethnics of Indonesian learners such as $[ð],[\theta],[\mathrm{v}],\left[\int\right],[3]$, and [t] . The reason for them being difficult is that they are commonly unfamiliar and some of them are not found in learners' native language. Therefore, such sounds tend to be pronounced differently with the target language sounds.

Then, other studies such as Tiono and Yostanto's (2008); Azizi, et. al, (2013); and Sridhanyarat (2017) also investigated how to pronounce marked-fricatives by learners and teachers of non-native speakers of English. All results of those studies depict that all respondents roughly have problems in pronouncing English fricatives. Tiono and Yostanto's (2008), for instance, state that the participants are unable pronouncing the fricative $[\theta]$ in the word-final position while Azizi, et. al, (2013) found that the participants are unable pronouncing the fricative [ $]]$ sound in the wordfinal position either. In contrast, Sridhanyarat (2017) revealed that only the marked fricative [S] tends to be easy for the participants to be pronounced. 
Based on the review aforementioned, the interlanguage of English language learners in phonology is an undeniable phenomenon to be taken into account. In this regard, the variability of acquiring marked sounds of English may contain fruitful depiction in the field of second language acquisition especially relating with learners' pronunciation of English where English is not their native language. This study decided to find out sound variants in interlanguage by opting foursound fricatives namely [ $\theta],[ð],\left[\int\right]$, and [3]. The reason to select these sounds is that several studies of interlanguage in English phonology show serious problems with those sounds pronounced by the learners of English since those sounds are absent in the learners' native language (Jehma and Phoocharoensil, 2014); (Tiono \& Yostanto's, 2008); Djajadiningrat's (2011); Azizi, et. al, (2013). Therefore, this study is aimed at finding out (1) marked sounds of English fricatives: [ $\theta]$, [ð], [ $]$, and [3] which are indicated as interlanguage variants; and (2) how interlanguage sound variants emerge based on surround the varying element

\section{Research method}

Research participants

There were 30-college students of English study program participating in this research to contribute the data. Those respondents were 18 females and 12 males purposively selected by their level of English speaking performance representing advance and intermediate proficiency levels.

Research instrument and procedure

Respondents were given two types of task namely word list reading and sentence reading of a reading text. Types of task, according to Ellis (1985b), have played an important role in interlanguage (IL) variability. In the first task, a pronunciation test of single word list was conducted in a closed room of the language laboratory. There were 20 -word types tested on the pronunciation test which represent those four fricatives.

Then, in the second task respondents were assigned to read the texts by the technique of reading aloud which of course their sounds were also recorded. There were three reading passages given in the reading task in which 20 -word types were also covered in those three passages. After all respondents completed the task, their pronunciations were evaluated to find the target words containing four fricatives targeted in this study. The target number of word tokens obtained from both tests was 600 tokens (20-word types multiplied by 30 respondents). The word tokens contained target sounds of fricative consonants [ $\theta],[ð],\left[\int\right]$, and [3] in word-initial, word-medial, and word-final positions to be used as the sound variables. The respondents' pronunciations were recorded and collected through English pronunciation application on smartphone which is socalled "TFlat". This mobile application contains various features of pronunciation test including recording sounds, scoring the pronunciation test through rating automatically one star to five stars by the device. Also, this application has native sound of words tested to be compared with the produced sounds by respondents. "TFlat" application is developed by android platform for educational purposes especially in teaching pronunciation of English. It can be downloaded freely on Google Play and be regarded as a friendly application for English teachers in teaching pronunciation.

\section{Data analysis}

After all respondents' pronunciations were recorded, the data were evaluated by reviewing the star rated by device; if the sound was rated in five stars, it would be regarded perfect and targetlike sounds. This was also treated with the same way when the sound was rated in four stars which 
means it was regarded as a target-like sound and still accurate by standard English. Hence, fricative sounds noticed by the application in four stars and higher do not necessary to be transcribed since they did not belong to IL sounds. Otherwise, for those sounds which are rated by the application in three stars and lower are classified as nontarget-like pronunciation or categorized as IL sounds of English. Then, these IL sounds of fricative were listed to administer. All of those sounds were calculated first on their percentage based on their positions emerge in words (word-initial, medial, and final positions). Then, those IL sounds must be transcribed carefully into phonetic transcriptions to determine IL variants of those four fricatives.

To confirm the instrument reliability of both tasks, firstly before being tested to the respondents the two types of instrument were evaluated with other 10 EFL students to measure its Cronbach's Alpha Coefficient for each task. The word list pronunciation task showed the reliability of $r=0.93$ while the sentence reading task show the computation result of $r=0.88$. This means both tasks of the instrument were highly reliable.

\section{Result}

From the data collected there are 600 tokens analyzed in relation to four marked fricatives: $[\theta]$, [ð], [J], and [3] in word-initial, word-medial, and word-final positions. Each fricative analyzed has 150 tokens of sound. Following tables depict findings to be more specific.

Table 1. The interlanguage form of fricative $[\theta]$

\begin{tabular}{lllll}
\hline Target sound variable & Sound positions & $\begin{array}{l}\text { IL } \\
\text { percentages }\end{array}$ & $\begin{array}{l}\text { sound sound } \\
\text { variants }\end{array}$ \\
\hline voiceless dental fricative $[\theta]$ & word-initial & $82 \%$ & {$[\mathrm{t}]$} \\
\cline { 2 - 4 }$(\mathrm{N}$ tokens $=150)$ & word-medial & $60 \%$ & {$[\mathrm{t}],[\mathrm{d}]$} \\
\cline { 2 - 5 } & word-final & $78 \%$ & {$[\mathrm{t}]$} \\
\hline
\end{tabular}

Table 1 indicates that fricative [ $\theta]$ has three variations of IL sound. More than $80 \%$ fricative $[\theta]$ pronounced as [t] in word-initial position; and $78 \%$ with the same IL form pronounced in the word-final. Meanwhile, in the word-medial position this fricative has two IL sound variants: [t] and $[\mathrm{d}]$ in which their percentage reach $60 \%$.

Table 2. The interlanguage form of fricative [ð]

\begin{tabular}{llll}
\hline Target sound variable & Sound positions & $\begin{array}{l}\text { IL } \\
\text { percentages }\end{array}$ & $\begin{array}{l}\text { IL sound } \\
\text { variants }\end{array}$ \\
\hline voiced dental fricative $[ð]$ & word-initial & $6 \%$ & {$[\theta],[\mathrm{d}]$} \\
\cline { 2 - 4 }$(\mathrm{N}$ tokens $=150)$ & word-medial & $0 \%$ & - \\
\cline { 2 - 4 } & word-final & $9 \%$ & {$[\mathrm{t}]$} \\
\hline
\end{tabular}

Table 2 shows that the voiced dental fricative [ð] has three IL sound variants from 94sound tokens analyzed. First, this fricative has IL sound variants of $[\theta]$ and $[\mathrm{d}]$ in the word-initial. Second, another IL form of [ð] pronounced as [t] in the word-final position. For those three-IL sounds of fricative [ð] seem not to give any significant number of occurrence since their percentages are less than 10\% compared with the target-like sound. However, respondents pronouncing this fricative in word-medial position with target-like sound mean that there is no IL form emerged on that sound position. 
Table 3. The interlanguage form of fricative [S]

\begin{tabular}{llll}
\hline Target sound variable & Sound positions & $\begin{array}{l}\text { IL sound } \\
\text { percentages }\end{array}$ & $\begin{array}{l}\text { IL sound } \\
\text { variants }\end{array}$ \\
\hline \multirow{2}{*}{$\begin{array}{l}\text { voiceless palatal fricative }\left[\int\right] \\
(\mathrm{N} \text { tokens }=150)\end{array}$} & word-initial & $6 \%$ & {$[\mathrm{~s}]$} \\
\cline { 2 - 4 } & word-medial & $7 \%$ & {$[\mathrm{z}]$} \\
\cline { 2 - 4 } & word-final & $38 \%$ & {$[\mathrm{~s}],[\mathrm{z}]$} \\
\hline
\end{tabular}

Table 3 depicts that fricative [J] has two variations of IL sound, those are [s] and [z]. The IL sound [s] emerges replacing sound [S] in word-initial and word-final positions while the IL sound $[\mathrm{z}]$ appears in word-medial and word-final positions. Those IL sounds are not significant in their percentages to the positions in word-initial and word-medial in which they only $6 \%$ and $7 \%$ emerges respectively. However, the IL sound of fricative [ $\left.\int\right]$ in word-final is higher in percentage than two previous positions which reaches $38 \%$.

Table 4. The interlanguage form of fricative [3]

\begin{tabular}{llll}
\hline Target sound variable & Sound positions & $\begin{array}{l}\text { IL sound } \\
\text { percentages }\end{array}$ & $\begin{array}{l}\text { IL sound } \\
\text { variants }\end{array}$ \\
\hline \multirow{2}{*}{$\begin{array}{l}\text { voiced palatal fricative [3] } \\
(\mathrm{N} \text { tokens }=150)\end{array}$} & word-initial & - & - \\
\cline { 2 - 4 } & word-medial & $41 \%$ & {$[\mathrm{~s}],[\mathrm{J}]$} \\
\cline { 2 - 4 } & word-final & - & - \\
\hline
\end{tabular}

The palatal fricative [3] indeed has no word tokens representing sounds in the word-initial and the word-final so that the depiction on Table 4 shows respondents' IL form only in pronouncing the marked sound in the word-medial position. From the data, the sound of fricative [3] has two IL forms which are indicated as [s], and [ $]$ ] where their percentage is about $41 \%$. Then, to what extent the interlanguage variability of those fricatives emerges and the possible reasons for their appearance based on surround elements; the following discussion is to reveal their phonological variations.

\section{Discussion}

Based on data findings, voiceless dental fricative [ $\theta]$ has IL forms of $[t]$ and $[d]$ on the word-medial position which emerge on word 'author' as [॰:tər] and [o:dər] instead of being pronounced as [o:Өər]. This phonological variation seems appear due to two factors: the influence of native language and the lack of learners' knowledge. The factor of native language influence is the most dominant in contributing interlanguage sound of this fricative.

In Tiono and Yostanto's (2008) study, Indonesian learners of English tend to replace the $[\theta]$ sound with other sounds which exist in their first language, i.e., $[t]$ and $[d]$. This is due to the fact that Indonesian has no consonant cluster 'th' in their native language which means they are more likely to pronounce the sound of first letter [ $t$ ] to utter words containing it than [ $\theta$ ] sound. In addition, the learners has limited information on how to pronounce 'th' in some other different words. In this regard, perhaps the consonant cluster 'th' is always sounded similarly as IL sound in 'they' 'there' 'this' or the like. Therefore, another IL variant [d] also coexist in the voiceless dental fricative $[\theta]$ among the Indonesian learners of English.

In terms of fricative [ð], the learners seem have less problems with this sound. This is depicted by only few respondents pronounce [ð] as [d] in word-initial and [t] in word-final which is less than $10 \%$ for each; and even respondents have no problem at all or no IL sound of [ð] in word-medial position. This is in contrast with Djajadiningrat's (2011), Jehma and Phoocharoensil 
(2014) where the voiced interdental fricative [ð] is difficult to pronounce. From both studies, the learners' errors to pronounce this kind of fricative were found the highest rate in the medial position which are contradicted with IL sounds found in this study.

Then, another phonological variation of marked fricative is the voicelss palatal fricative [J]. This fricative is well-pronounced by respondents especially in word-initial and word-medial positions but it is not in the word-final one where the IL form much higher than in two other positions. To be more specific, the sound of [S] has a dominant IL form i.e., [s] in the word-final which appears in the word 'cash'. This study tested two words of 'cash' and 'fish' to find whether any IL variant emerges on the same sound ending. Then the data show that the IL variant of [s] appears in 'cash' which is pronounced as [kæs] instead of [kæ $\left.\int\right]$ but not in 'fish'. This result confirms to Azizi, et. al, (2013) where their study with non-native ESL teachers who has L1 are Malay found that the $\left[\int\right]$ sound in the final position is the highest frequency compared to the other positions.

In contrast, this study did not show the variant [s] appearing on 'fish' albeit in the same sound position. Based on the surround element, in 'cash' the sound [ $]$ ] is preceded by vowel sound [æ] so that the IL sound likely emerges. However, when the fricative sound was preceded by vowel sound [I] as in 'fish', the IL variant of [s] was disappear. From this data, it is implied that the phonological variation which emerges on fricative [S] likely depends on the vowel sound preceding it. Yet the more possible reason is that the word 'cash' has its similar syllabic counterpart with another word 'case' where the latter is more commonly found by the learners than the former, so that the latter is frequently pronounced the learners in every speaking context. Therefore, respondents tend to pronounce 'cash' same as pronouncing 'case' where sound [s] in 'case' is similar with learner's L1 sound. This phenomenon confirms Flege's (1995) study that L2 sounds that are similar to L1 sounds are difficult to acquire as the learner does not perceive them or classify them as different and hence does not set up a new category of contrast. It goes without saying, the similarity factor in phonetic is also the reason of IL sound appearance in this case.

Meanwhile, voiced palatal fricative [3] has two IL variants: [s] and [J] in word-medial position but the more dominant IL sound is [J] than [s]. Most learners pronounced 'television' and 'vision' as [telivi $\int \mathrm{n}$ ] and [VI $\mathrm{n}$ ] respectively, though some pronounced as [telivisn] and [visn]. This is in line with Djajadiningrat's (2011) study that L1 Indonesian incorrectly pronounced the target sound of [3] in the medial position. However, in Djajadiningrat the target sound [3] was substituted with the only one sound [s] but not [J] as shown in this study.

From the data of this study, the IL variant [J] emerges replacing fricative [3] when it is followed by a nasal alveolar [n] but not in a sound which is followed by an approximants alveolar [r] such as in 'pleasure' and 'leisure' where some learners had no problem pronouncing both as [plezər] and [lezər] respectively. Moreover, this study finding implies that the appearance of IL sound of fricative [3] does not merely fit based on the sound position but it is more likely influenced by the surround of syllabic sound too. It refers, for instance, to two previous words i.e., 'television' and 'vision', in which learners pronounce the syllabic sound of the suffix -sion tending to generalize it by sounding [ $[\mathrm{n}]$ or [sn] like in the suffix -tion. This is again due to respondents' familiarity with related sounds.

\section{Conclusion}

The Indonesian learners of English indeed have interlanguage forms on marked sounds of fricatives [ $\theta],[ð],\left[\int\right]$, and [3]. The variants of IL sound mostly depend (but not permanently) on certain positions where those sounds emerge. The analysis depicts that voiceless dental fricative 
[ $\theta$ ] has two variations of IL sound as [t] and [d] in the word-medial but not in the two other positions. However, the voiced palatal fricative [3] which has IL variants of [s] and [S] tends to show the other feature of variability in phonology which is more likely influenced by the surround of its syllabic sound. Then, the voiceless palatal fricative [ $\left.\int\right]$ has also two variations of IL form i.e., $[\mathrm{s}]$ and $[\mathrm{z}]$ which emerge in the word-final but they do not appear in the two other positions. To conclude, the variability phenomena of interlanguage phonology by Indonesian learners of English depends on some factors such as the generalization of pronunciation by similar-ending sounds, the certain vowel sound preceding marked sounds, and the absence of consonant clusters in learners' native language which bears the variation of certain marked fricatives of English.

\section{Recommendations}

The findings of this research will lead to the implications of acquiring fricatives for Indonesian learners of English. As known, Indonesian learners who come from various ethnic groups and each has its regional language (as their mother tongue) automatically have their own vernacular in obtaining the pronunciation of English. Their vernaculars bear a spectrum of interlanguage in English pronunciation. Since interlanguage variability in the phonological perspective is of course systematic, systematic variability is determined by linguistic context and situational context. Indonesian English learners systematically vary their choice of interlanguage forms according to whether they use a vernacular style of unplanned pronunciation or a careful style of planned pronunciation. In specific, the choice of form on how Indonesian learners pronounce marked fricative sounds of English is also influenced by the surround of the phonological features of the targeted fricative sounds. So, the implication for second language acquisition from this variation pattern is the extent to which the learner monitors his or her own fricative sounds. Heavy monitoring is possibly to result in a careful style of learners in acquiring the fricative sounds while a low level of monitoring will result in a vernacular style, which is more natural and more systematic (Song, 2012).

Furthermore, this research suggests to Indonesian teachers of English that they should also be aware that variations in fricative sounds spoken by Indonesian learners are not serious errors in acquiring English pronunciation, especially in the context of interlanguage variability. Since phonological variations are systematic, Indonesian learners of English must familiarize themselves with the correct pronunciation of fricative sounds (at least nearly native-like) so that the vernacular variants will eventually disappear and be corrected along with getting through the interlanguage phase of the learner's language. However, the findings of this research are far from enough. This is only the beginning to uncover the acquisition of English pronunciation for Indonesian learners, especially regarding phonological variations of fricative on learner's language.

Declaration of conflicting interest

The researcher declares no conflict of interest.

Acknowledgement

The author is very grateful with Prof. Joni Bungai, the Dean of Faculty of Teacher Training and Education of Palangka Raya University who facilitated him in obtaining the grant funding from the university to finance this research. Also, the author thanks to Raynaldi Adilasta, who assisted him to collect the data and preparing all facilities along the data taken. 


\section{References}

Azizi, A. A., Jamil, S. S., \& Omar, H. M. (2013). Debunking the notion of nativization in the pronunciation variation at segmental level among non-native ESL teachers in Sabah, Malaysia. International Journal of Pedagogical Innovations, 1(10), 1-10. https://doi.org/10.12785/ijpi/010101

Bialystok, E., \& Sharwood, S. M. (1985). Interlanguage is not a state of mind: An evaluation of the construct for second-language acquisition. Applied Linguistics, 6(2), 101-117. https://doi.org/10.1093/applin/6.2.101

Celce-Murcia, M., Briton, D. M., \& Goodwin, J. M. (1996). Teaching pronunciation: A reference for teachers of English to speakers of other languages. Cambridge: Cambridge University Press.

Corder, S.P. (1971). Idiosyncratic dialects and error analysis. International Review of Applied Linguistics, 9(2), 147-160. https://doi.org/10.1515/iral.1971.9.2.147

Dickerson, L. J. (1975). The Learner's interlanguage as a system of variable rules. TESOL Quarterly, 9(4), 401-407. https://www.jstor.org/stable/3585624

Djajaningrat, I. (2011). The Mapping of Pronunciation Error. Jakarta: Universitas Darma Persada.

Ellis, R. (1985a). Sources of variability in interlanguage. Applied Linguistics, 6(2), 118-131. https://doi.org/10.1093/applin/6.2.118

Ellis, R. (1985b). Understanding Second Language Acquisition. Oxford: Oxford University Press.

Ellis, R. (1988). The effects of linguistic environment on the second language acquisition of grammatical rules. Applied Linguistics, 9(3), 257-274. https://doi.org/10.1093/applin/9.3.257

Jehma, H., \& Phoocharoensil, S. (2014). L1 Transfer in the Production of Fricatives and Stops by Pattani-Malay Learners of English in Thailand. Asian Social Science, 10(7), 67-78. http://dx.doi.org/10.5539/ass.v10n7p67

Fasold, R. (1984). Variation theory and language learning. In Trudgill, P (ed), Applied Sociolinguistics. London: Academic Press.

Fauzi, I. (2018). Teaching English in Multiethnic Classroom: A case study on phonemic variation of secondary school students in Central Kalimantan. Proceedings of the 1st International Conference on Social Sciences Education: Multicultural Transformation in Education, Social Sciences and Wetland Environment (ICSSE 2017), 147, 153-158. https://doi.org/10.2991/icsse-17.2018.36

Flege, J. E. (1995). Second language speech learning: theory, findings, and problems. In W. Strange (Ed.), Speech Perception and Linguistic Experience: Issues in Cross-Linguistic Research (pp. 233-277). York Press. Timonium, MD. http://jimflege.com/files/Flege_in_Strange_1995.pdf

Gass, S. M., \& Selinker, L. (2008). Second language acquisition: An introductory course (3rd ed.) New York: Taylor \& Francis.

Nemser, W. (1971). Approximate systems of foreign language learners. International Review of $\begin{array}{llr}\text { Applied } & \text { Linguistics, } & \text { 115-124. }\end{array}$ https://www.degruyter.com/document/doi/10.1515/iral.1971.9.2.115/html

Nozadze, A. (2012). Dealing with fossilized errors while teaching grammar. Journal of Education, 1(1), 41-46. https://www.semanticscholar.org/paper/Dealing-with-Fossilized-Errors-whileTeaching-Nozadze/ebfd40c9320b53978b0529b7d4dbd6e54c644f41

Osborne, D. M. (2008). Systematic differences in consonant sounds between the interlanguage phonology of a Brazilian Portuguese learner of English and standard American English. Ilha do Desterro, 55, 111-132. https://www.redalyc.org/articulo.oa?id=478348693006 
Richards, J.C. (1974). Error analysis: Perspetive on second language acquisition. London: Longman.

Selinker, L. (1972). Interlanguage. International Review of Applied Linguistics, 10(3), 209-231. http://dx.doi.org/10.1515/iral.1972.10.1-4.209

Song, L. (2012). On the Variability of Interlanguage. Theory and Practice in Language Studies, 2(4), 778-783. http://dx.doi.org/10.4304/tpls.2.4.778-783

Sridhanyarat, K. (2017). The Acquisition of L2 Fricatives in Thai Learners' Interlanguage. 3L: The Southeast Asian Journal of English Language Studies 23(1), 15-34. http://doi.org/10.17576/3L-2017-2301-02

Tarone, E. (1988). Variation in Interlanguage. London: Edward Arnold.

Tiono, N. I., \& Yostanto, A. M. (2008). A Study of English Phonological Errors Produced by English Department Students. k@ta, 10(1), 79-112. http://dx.doi.org/10.9744/kata.10.1.79112

Utumber S. J. K., Yusoff, N., \& Abdul, M. C. M. A. (2014). Language Identity: Variability in Phonology in Different Races in Malaysia. AJELP: Asian Journal of English Language and Pedagogy, 2, 74-82. https://ejournal.upsi.edu.my/index.php/AJELP/article/view/1101

Wolfram, W. (2006). Variation and Language: An overview. Encyclopedia of Language and Linguistics (2nd ed.), 333-341. Boston: Elsevier. https://www.sciencedirect.com/referencework/9780080448541/encyclopedia-of-languageand-linguistics

Young, R. (1991). Variation in interlanguage morphology. New York: Peter Lang Publishing, Inc. 